\title{
The relationship between forest cover and diet quality: a case study of rural southern Malawi
}

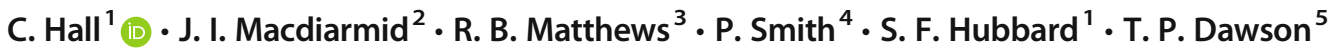

Received: 20 March 2018 / Accepted: 12 April 2019 / Published online: 20 May 2019

(C) The Author(s) 2019

\begin{abstract}
The importance of forests in supporting the well-being of poor rural communities cannot be overstated, not only for improving food security but also for biodiversity conservation. For many people living in developing regions of the world, forests provide healthy and nutrient-dense foods which can improve overall diet quality and act as a safety net during times of hardship. Forests can also provide a source of income and facilitate certain agricultural practices, potentially allowing for poverty alleviation and mitigation. This study examined whether there was a relationship between forest cover and diet quality at the household level in rural southern Malawi. Nutrition data for 2084 households, collected as part of the 2010/11 Third Integrated Household Survey for Malawi (IHS3), were compared with a satellite-based land-cover map of Malawi. Households located in areas with a high percentage forest cover had significantly improved vitamin A adequacy compared to households in less forested areas. Also, vitamin A intake was significantly improved by consumption of wild plant foods. Forest cover was not associated with any other indicators of diet quality, but a number of social and demographic factors were significant determinants, including household size, education and access to markets. Further investigation of these associations is imperative at a time when forests are being cleared at an alarming rate to make way for agricultural production.
\end{abstract}

Keywords Forests $\cdot$ Wild foods $\cdot$ Diet quality $\cdot$ Micronutrient intake $\cdot$ Malawi $\cdot$ Dietary diversity

\section{Introduction}

\subsection{Background}

Forest landscapes provide human populations across the world with a range of important ecosystem services. These include provisioning (e.g., food and fuel), regulating (e.g., climate regulation and pollination), supporting (e.g., nutrient cycling), and cultural (e.g., spiritual benefits) services, which are all essential for human health and well-being (Colfer et al.

C. Hall

c.y.hall@dundee.ac.uk

J. I. Macdiarmid

j.macdiarmid@abdn.ac.uk

R. B. Matthews

robin.matthews@hutton.ac.uk

P. Smith

pete.smith@abdn.ac.uk

S. F. Hubbard

s.f.hubbard@dundee.ac.uk
2006; Foley et al. 2011; Poppy et al. 2014; Sandifer et al. 2015). Despite these valuable benefits, the world's forests are being cleared at an alarming rate to make way for agricultural expansion at the expense of both biodiversity and human well-being (Chappell and LaVelle 2009; Hosonuma et al. 2012; Johnson et al. 2013; Lanz et al. 2017; Phalan et al. 2011). The most extensive and rapid deforestation has occurred in the tropics (Hansen et al. 2013; Hosonuma et al. 2012), and in particular sub-Saharan Africa where deforestation rates are twice the world average (Austin et al. 2017;

T. P. Dawson

rry.dawson@kcl.ac.uk

1 School of Social Sciences, University of Dundee, Scotland, UK

2 The Rowett Institute, University of Aberdeen, Scotland, UK

3 James Hutton Institute, Scotland, UK

4 Institute of Biological and Environmental Sciences, University of Aberdeen, Scotland, UK

5 Department of Geography, King's College, London, UK 
d'Annunzio et al. 2015). These losses are particularly pertinent for poor, rural communities in the developing world (such as sub-Saharan Africa) where people are directly dependent on forests for their livelihoods and well-being (Johnson et al. 2013; Palmer and Di Falco 2012).

The relationship between forests and human nutrition is not yet fully understood, yet a growing body of evidence suggests that having access to natural forest landscapes is beneficial for diet quality (Broegaard et al. 2017; Fungo et al. 2016; Galway et al. 2018; Ickowitz et al. 2013; Ickowitz et al. 2016; Johnson et al. 2013; Reed et al. 2017; Rowland et al. 2016). While the drivers of these associations are often unclear, there are a number of pathways by which natural forest landscapes can affect diet quality (Fig. 1). The first and most direct of these is the provision of wild forest foods (hereafter referred to as forest foods). Forest foods are known to be commonly consumed across the world, particularly in developing countries, although studies have shown considerable variation in their consumption rates and contribution to diets across different socio-ecological settings (Broegaard et al. 2017; Fungo et al. 2016; Powell et al. 2015; Reed et al. 2017; Rowland et al. 2016). It is important to note that "wild foods" are not the same as "forest foods". Wild foods refer to any uncultivated foods that can be collected or hunted from natural landscapes (including around the home, rivers, lakes, forests, and even agricultural land) (Bharucha and Pretty 2010), while forest foods are a subset of wild foods and include only uncultivated foods collected or hunted from natural forest landscapes (Rowland et al. 2016). Forest foods typically include fruits, vegetables, wild roots and tubers, nuts, seeds, leaves, palms, insects and wild animals, which tend to have high concentrations of micronutrients (Turner et al. 2011; Vinceti et al. 2008). For example, animal source foods from forests (vertebrate and invertebrate) provide protein and fat, and are rich in highly bio-available iron, zinc and vitamin $\mathrm{B}_{12}$, while wild plant foods are often important contributors of micronutrients, such as vitamin $\mathrm{A}$, iron, folate, niacin and calcium (Ickowitz et al. 2016; Powell et al. 2011; Vinceti et al. 2013). Forest foods rarely provide staple foods (such as maize) or make up the majority of the diet; rather they supplement what is available from agricultural production (Arnold et al. 2011). As a result, consumption of these foods can increase overall diet quality by increasing dietary diversity (Fungo et al. 2016; Ickowitz et al. 2016; Ickowitz et al. 2013; Johnson et al. 2013). Forest foods can also act as a safety net or buffer during times of food shortages, for instance during times of illness where one or more members of a household are unable to work, crop failure and other kinds of external shock (Arnold et al. 2011). This may be particularly important for vulnerable populations such as families who do not own land, and households headed by women (Galway et al. 2018; Kamanga et al. 2009). Furthermore, forest foods are particularly important in rural areas where there is poor market access (Harris and Mohammed 2003; Ickowitz et al. 2016).

There are also a number of more indirect pathways by which forests can influence diet quality. The collection, use and sale of non-timber forest products (NTFPs) can improve livelihoods and provide a source of income for rural communities (Aerts and Honnay 2011; Ahenkan and Boon 2011; Belcher et al. 2005; Heubach et al. 2011; Hickey et al. 2016; Pfund et al. 2011; Schaafsma et al. 2014; Vinceti et al. 2013). Such products can include any wild plant or animal resource

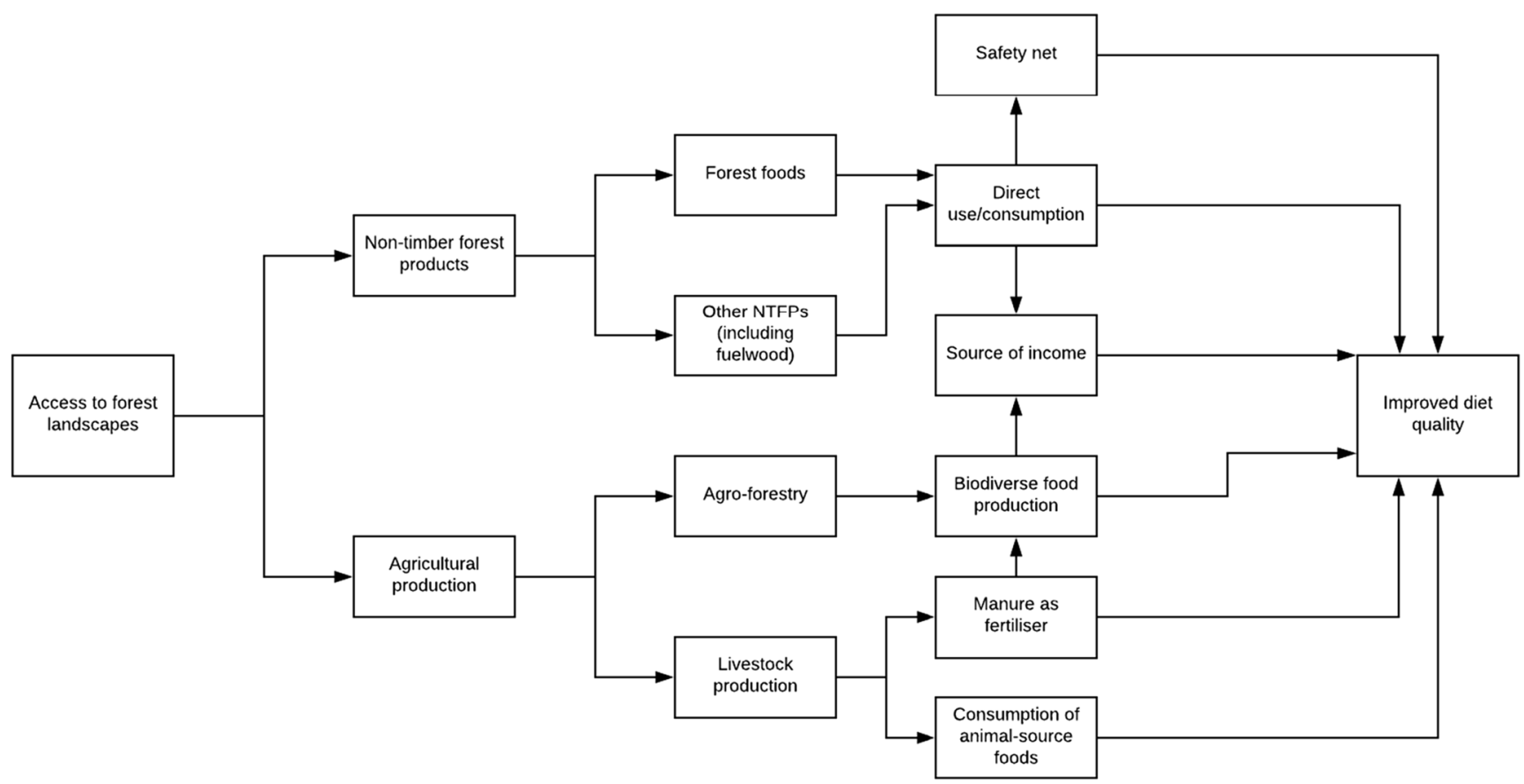

Fig. 1 Conceptual framework illustrating the pathways by which access to natural forest landscapes can improve diet quality 
from the forest, such as forest foods, herbs, medicines, fuelwood, other wood (i.e. for making crafts), thatch grass, reeds, etc. (Shakleton and Shakleton 2004). Access to NTFPs is particularly important for the poorest and most vulnerable households as they are able to use these affordable (and local) resources to meet their needs (shelter, food, medicine), which can negate the use of scarce cash resources allowing them to accumulate assets for more secure livelihoods, leading to poverty mitigation and alleviation (Baudron et al. 2017; Shakleton and Shakleton 2004; Shakleton et al. 2007; Vedeld et al. 2007). Income generated from the sale of NTFPs can be critical in supporting livelihoods (Aerts and Honnay 2011; Angelsen et al. 2014; Hickey et al. 2016; Schaafsma et al. 2014; Vinceti et al. 2013). For example, a study by Angelsen et al. (2014) compared environmental income across 24 developing countries, concluding that $28 \%$ of total household income came from the sale of natural goods, $77 \%$ of which came from natural forests. More specifically, in West Africa it is estimated that between four and five million women earn $80 \%$ of their income from the collection, processing and marketing of naturally occurring shea tree nuts (FAO 2013). Likewise, a study carried out in the Chiradzulu district of southern Malawi found that forest income made up approximately $15 \%$ of people's total income, yet this figure was much higher (around 65\%) for resource poor farmers with limited access to agricultural land and a high representation of female heads (Kamanga et al. 2009). If this income is used to purchase nutritious and diverse food items available in markets, dietary quality is likely to be improved. Furthermore, fuelwood is a vitally important NTFP and an oftenoverlooked necessity for ensuring healthy diets (Galway et al. 2018). An estimated 2.4 billion people rely on fuelwood for food preparation and preservation, particularly in subSaharan Africa (Brown et al. 2014; FAO 2013).

Another key pathway by which forests can improve diet quality is by supporting diverse agricultural production. Forests can support agricultural production in three main ways. Firstly, biodiverse forests provide supporting ecosystem services such as pollination, pest control and enhanced nutrient availability which are crucial for agricultural systems (Reed et al. 2017). Similarly, in areas characterised by low soil fertility (such as sub-Saharan Africa) trees can maintain soil fertility (Foli et al. 2014). Secondly, access to forests can facilitate the use of swidden cultivation and agroforestry techniques. There is some evidence to suggest that agricultural practices such as these are more likely to produce diverse and high quality foods with positive impacts on diet quality (Ickowitz et al. 2016; Pimentel et al. 1997; Reed et al. 2017; Vinceti et al. 2013). Indeed, recent evidence has shown that agricultural biodiversity is associated with greater dietary diversity at the household and individual levels (Jones 2017; Jones et al. 2014). It should be noted, however, that a study by Termote et al. (2012) found that a highly biodiverse environment did not contribute to improved diet quality, as wild foods were rarely consumed, despite being readily available, which was inconsistent with the authors' expectations. Thirdly, a less well-researched pathway is the flow of biomass from forest land to surrounding farming households which can indirectly improve diet quality. A study by Baudron et al. (2017) found that proximity to the Munesa Forest in southern Ethiopia was positively associated with dietary diversity, despite households not consuming or selling forest foods. The relationship was explained by the use of biomass as livestock feed, which increased herd size, having two main benefits; 1) manure from livestock was used as a fertiliser in home gardens, leading to the production of nutrient-dense food, and 2) larger livestock herds resulted in more frequent consumption of animal source foods, leading to greater dietary diversity.

Although the current literature is limited, some studies have examined the linkages between forest cover and diet quality specifically in Malawi. A study by Fisher et al. (2010) found that households in Malawi's Mulanje district reported using forest foods during times of famine, with $67 \%$ of households classing these foods as "very important" for this purpose. However, forest foods were not exclusively used during such times; with forest foods comprising $10 \%$ of meals even when agricultural produce was abundant (Fisher et al. 2010). Similarly, a recent study by Rowland et al. (2016) showed that households in Malawi were among the greatest users of forest foods when compared to 23 other tropical countries. In Malawi, $79.6 \%$ of households were forest food users, with the site being classed as "forest food supplementation". This is described as widespread but low level consumption of forest foods (Rowland et al. 2016). Moreover, a study by Maseko et al. (2017) found that children in four villages of Malawi's Zomba district frequently consumed and sold wild foods. Wild foods were very important for dietary diversity in these villages with a total of 119 wild food species listed across the four sites. Furthermore, a study by Johnson et al. (2013) linked data from the Malawi Demographic and Health Survey (DHS) with satellite remote sensing data on forest cover, and found that forest cover is associated with improved nutritional outcomes and reduced risk of diarrheal disease in children. Children living in areas where forest cover was lost between 2000 and 2010 were $29 \%$ less likely to consume vitamin A rich foods (certain fruits and vegetables) and 19\% less likely to have a diverse diet than children living in areas with no net change in forest cover during the same period. In the present study, we build on the study of Johnson et al. (2013) by linking Malawi survey data with forest cover at the subdistrict level. While Johnson et al. (2013) linked household nutritional and anthropometric outcomes with forest cover at $5 \mathrm{~km}$ resolution, we examined the relationship between diet quality and forest cover at a more regional level. We assessed whether living in areas that have greater forest cover was beneficial for diet quality, regardless of individual household 
access to forest landscapes. This assumes that the advantages which can arise from forested landscapes (direct consumption of wild foods, income generation, etc.) may benefit the wider community in that area, suggesting some connectivity between households/villages within an area.

\subsection{Study site selection}

Southern Malawi was selected as an appropriate study site due to the very high rates of poverty, undernutrition and dependence on ecosystem services (Johnson et al. 2013). The most recent estimates from the Food and Agriculture Organisation of the United Nations (FAO) suggest that $26.3 \%$ of the Malawian population were undernourished in 2016 (an increase from $21.8 \%$ in 2010) (FAO et al. 2018). It should be noted that "undernourishment" is defined here as the proportion of a population whose dietary energy intake is less than their requirements and does not take into account micronutrient intake. Undernourishment in the southern region is considerably higher than the country average, with a recent study reporting a prevalence of $64.2 \%$ (Dobbie 2016). As well as dietary energy deficiency, micronutrient deficiencies are widespread in Malawi, particularly iron, zinc and vitamin A. A survey conducted by Verduzco-Gallo et al. (2014) found that in rural households in Malawi's southern region, $49 \%$ were iron deficient, $55.8 \%$ were zinc deficient and $69.4 \%$ were vitamin A deficient. Furthermore, almost four in ten (37\%) children were stunted (low height for age) and $12 \%$ of children were underweight (NSO 2017). These figures vary among regions, with the southern region having the poorest health outcomes. Around $85 \%$ of Malawians live in rural areas where poverty rates are highest and depend on forest resources for food, fuel and maintenance of their livelihoods (UN 2011). Despite this reliance on natural forests, estimates suggest that Malawi has one of the highest deforestation rates in southern Africa (Hansen et al. 2013). A recent study by Bone et al. (2017) estimated a $36 \%$ loss $\left(12,760 \mathrm{~km}^{2}\right)$ of original forest area between 1972 and 2009 in Malawi. However, the study also estimated there was $11,161 \mathrm{~km}^{2}$ of new forest establishment during the same period, resulting in a net loss of $1599 \mathrm{~km}^{2}$ (which is relatively modest). Despite the high rates of afforestation in Malawi, it is unlikely that the new forest land would have the same value in terms of ecosystem services and biodiversity as the remaining original forests (Bone et al. 2017; Mwase et al. 2007). Moreover, a study by Hansen et al. (2013) estimated that between 2000 and 2012, Malawi lost $1290 \mathrm{~km}^{2}$ of its tree cover, which equates to $1.4 \%$ of total forest cover per annum. This figure is relatively high (but not the highest) when compared with surrounding countries: for example, Mozambique, Zambia, Zimbabwe, Botswana and South Africa were estimated to have lost $2.8 \%, 1.8 \%, 1 \%, 0 \%$ and $0.8 \%$ per annum, respectively (Hansen et al. 2013).

\subsection{Hypotheses and rationale}

The aim of this study was to explore the relationship between forest cover and diet quality in the southern region of Malawi. We hypothesised that higher percentages of forest cover would be associated with improved diet quality for households in these areas. In addition, we examined a number of household level variables to better understand the potential mediating effects they may have on the relationship between forest cover and diet quality. Firstly, we hypothesised that larger households would experience poorer diet quality outcomes due to more limited resources and increased pressure on consumption (Koppmair et al. 2016; Naser et al. 2014; Pei et al. 2018; Powell et al. 2017). Secondly, we hypothesised that better educational attainment would result in improved diet quality as has been shown in a number of studies (Fungo et al. 2016; Ickowitz et al. 2013; Jones et al. 2014; Snapp and Fisher 2015). Thirdly, we hypothesised that better access to markets would be positively correlated with diet quality, as markets provide a platform for the purchase and sale of produce (Ickowitz et al. 2013; Koppmair et al. 2016; Sibhatu et al. 2015; Snapp and Fisher 2015). While forests can provide diverse and nutritious foods unmediated by markets (which may be particularly important in countries such as Malawi where markets function poorly), thus improving diet quality, we hypothesised that both forest and non-forest dwellers would benefit from better market access given that the sale of forest products requires a marketplace in order to derive income. Lastly, we hypothesised that consumption of wild plant foods would result in improved diet quality. Moreover, it is likely that consumption of wild foods would be affected by forest cover and other household factors.

The need to better understand the relationship between forests and diet quality is vital not only for ensuring human wellbeing, but also in terms of forest and biodiversity conservation. Given that Malawian diets are largely dominated by staple foods such as maize, cassava and rice, and thus tend to lack quality as opposed to quantity, understanding the role of forest foods is particularly important and should be integrated into future agricultural policies (Aberman et al. 2018). This study aims to add to the small but growing body of literature that links forests and forest-based ecosystems with diet quality, highlighting an important area for future research.

\section{Data and methods}

\subsection{Land cover data}

Land cover data for Malawi was obtained from the publicly available Malawi Spatial Data Portal (MASDAP) (http:// www.masdap.mw/layers/) and ArcGIS Desktop was used to examine land cover across 69 enumeration areas (EA) in the 
southern region. An EA is defined as the smallest operational area established for the 2008 Malawi Population and Housing Census, with well-defined boundaries. The Malawi Landcover 2010 (Scheme 2) was used as a base map. The landcover map was generated from Landsat Thematic Mapper (Landsat 5) satellite sensor using a supervised classification method. Administrative boundaries for the EAs were set using the Global Administrative Unit Layers (GAUL) vector layer (administrative boundaries level 3). The land cover groups included in the raster layer were forest land (sparse, moderate and dense), grassland (closed and open), shrubland (closed and open), cropland (perennial and annual) and wetland. We calculated percentage cover of forest land (sparse moderate and dense combined) for each EA using spatial analyst tools within ArcGIS. Thus, each EA was allocated a value for percentage forest cover which was later linked to nutrition data for households within each EA.

\subsection{Dietary data}

\subsubsection{Dietary intake data}

The nutrition data used in this study were collected as part of the 2010/11 Third Integrated Household Survey for Malawi (IHS3). The IHS3 data were used (as opposed to the more recent IHS4 data) to match with the land cover map of Malawi which was available for the year 2010. The IHS3 is a nationally representative survey, designed to assess various aspects of household welfare in Malawi. Food consumption data were collected by the IHS3 using questionnaires whereby participants recalled all food consumed by the household over a period of seven days preceding the interview. There are a total of 135 items listed in the IHS3 including beverages and foods not prepared in the household (i.e. meals eaten out of the home). Participants were issued with photo aids in order to estimate quantities of the items consumed. The majority of items were therefore reported in local units such as pails, bunches and heaps. These local measurement units were converted into standard units $(\mathrm{kg})$ using conversion tables created by Joy et al. (2015). The IHS3 was conducted over the course of one year and so households were surveyed during different seasons.

The following indicators were used to assess diet quality at the household level, from self-reported dietary intakes:

(i) Dietary energy consumption (kcals per day)

(ii) Dietary energy adequacy (\%)

(iii) Iron intake (mg/day)

(iv) Zinc intake (mg/day)

(v) Vitamin A intake (RAE $\mu$ g/day)

(vi) Micronutrient adequacy (\%)

(vii) Dietary diversity (Household Dietary Diversity Score [HDDS])
Given that healthy diets require both quantity (i.e. sufficient energy) and quality (i.e. sufficient intake of macro- and micronutrients essential for health); we used the above indicators as proxies of overall diet quality. Iron, zinc and vitamin A were selected as micronutrients of interest as these are the most commonly deficient nutrients in Malawi and many other developing countries (NSO 2017), and are therefore useful indicators of diet quality.

\subsubsection{Household intake}

Using the IHS3 consumption data we estimated the energy and micronutrient intake of 2267 rural households across the 69 EAs in southern Malawi. The energy and nutrient intakes were estimated using food composition tables for West Africa (Stadlmayr et al. 2012) and Mozambique (Korkalo et al. 2011). In line with Bermudez et al. (2012), households with implausible energy intakes ( $<500$ and $>6000 \mathrm{kcals} /$ household member/day) were removed from the sample. This comprised $4.4 \%$ of the households, bringing the total number of households to 2084 (9396 individuals). Since households differed in composition, we used an adult male equivalent (AME) for intakes, as outlined by Weisell and Dop (2012). Data relating to household structure (age and sex of individual members) was obtained from the IHS3 data set which allowed us to estimate intra-household allocation of food using AME values as a proxy. An AME value was estimated for each person following guidelines outlined by the FAO report on human energy requirements (FAO 2001). The AME values are shown in Table 1. Individual AME values were summed for each household to give total household AME. Total household nutrient intakes were then divided by household AME values to give mean intakes per AME for each household. This allowed the direct comparison of households of different sizes and compositions. It is important to note that the identification of pregnant or lactating women was not available and so we could not adjust their AME values accordingly.

\subsubsection{Dietary adequacy}

In order to calculate adequacy of the household diets, estimated intakes were compared with Estimated Average Requirements (EAR) as promulgated by the Institute of Medicine (IOM 2001). Dietary energy adequacy of each household was calculated by comparing the mean household values with the benchmark value for an 18-30 year old male (3000 kcal/day). Recommended nutrient intakes (RNI) of iron, zinc and vitamin A were based on the World Health Organisation (WHO) dietary recommendations (WHO 2004). RNIs are defined by the WHO as the average daily nutrient intake level that meets the needs of almost all apparently healthy individuals in an age- and sex- specific population group. For zinc, we assume a low bioavailability factor as 
Table 1 Adult male equivalent (AME) units applied to individual household members from the IHS3 survey

\begin{tabular}{|c|c|c|c|c|}
\hline \multirow[t]{2}{*}{ Age range (years) } & \multicolumn{2}{|l|}{ Male } & \multicolumn{2}{|c|}{ Female } \\
\hline & AME & Energy requirement (kcal/day) & AME & Energy requirement ( $\mathrm{kcal} /$ day) \\
\hline $0-1$ & 0.21 & 639.33 & 0.20 & 590.16 \\
\hline $1-2$ & 0.31 & 934.43 & 0.28 & 836.07 \\
\hline $2-3$ & 0.37 & 1106.56 & 0.34 & 1032.79 \\
\hline $3-4$ & 0.41 & 1229.51 & 0.38 & 1131.15 \\
\hline $4-5$ & 0.44 & 1327.87 & 0.41 & 1229.51 \\
\hline $5-6$ & 0.48 & 1450.82 & 0.43 & 1303.28 \\
\hline $6-7$ & 0.52 & 1549.18 & 0.47 & 1401.64 \\
\hline $7-8$ & 0.56 & 1672.13 & 0.51 & 1524.59 \\
\hline $8-9$ & 0.60 & 1795.08 & 0.56 & 1672.13 \\
\hline $9-10$ & 0.65 & 1942.62 & 0.61 & 1819.67 \\
\hline $10-11$ & 0.70 & 2114.75 & 0.66 & 1967.21 \\
\hline $11-2$ & 0.77 & 2311.48 & 0.70 & 2114.75 \\
\hline $12-13$ & 0.84 & 2508.20 & 0.75 & 2237.70 \\
\hline $13-14$ & 0.91 & 2729.51 & 0.78 & 2336.07 \\
\hline $14-15$ & 0.98 & 2950.82 & 0.80 & 2409.84 \\
\hline $15-16$ & 1.04 & 3122.95 & 0.82 & 2459.02 \\
\hline $16-17$ & 1.09 & 3270.49 & 0.82 & 2459.02 \\
\hline $17-18$ & 1.11 & 3344.26 & 0.82 & 2459.02 \\
\hline $18-30$ & 1.00 & 3000.00 & 0.79 & 2360.66 \\
\hline $30-59$ & 0.97 & 2901.64 & 0.77 & 2311.48 \\
\hline $60-100$ & 0.80 & 2409.84 & 0.69 & 2065.57 \\
\hline
\end{tabular}

Malawian diets are largely maize-based and high in phytates which inhibit zinc absorption (Manary et al. 2000). For iron, we assume a bioavailability factor of $5 \%$ to represent Malawian diets which are low in animal sources of iron (haem iron) (IOM 2001). For each nutrient, we calculated the required intake of each person in the household (based on age and sex) and summed these values to give a "total household requirement". This value was then compared with the reported household intake to give an estimate of the percentage adequacy of each nutrient.

\subsubsection{Dietary diversity}

Dietary diversity was used as a proxy for diet quality (Galway et al. 2018; Johnson et al. 2013; Jones et al. 2014). Diets with a greater variety of foods or food groups are often associated with more adequate nutrient intakes (Hatloy et al. 1998; Steyn et al. 2006), and improved child and adult anthropometric outcomes (Arimond and Ruel 2004; Rah et al. 2010). In this study, dietary diversity was assessed using the HDDS which is based on the number of different food groups households have consumed over the recall period (Swindale and Bilinsky 2006). Given that the HDDS was originally validated for use on $24 \mathrm{~h}$ dietary recall data, we constructed a modified version based on seven day recall data and in line with Jones et al. (2014), as no $24 \mathrm{~h}$ data were available in the IHS3 data set.
The 135 food items listed in the IHS3 were categorized into 12 different food groups; (1) cereals, (2) roots and tubers, (3) vegetables, (4) fruits, (5) meat, poultry and offal, (6) eggs, (7) fish and seafood, (8) pulses, legumes and nuts, (9) milk and milk products, (10) oils and fats, (11) sugar and honey, and (12) miscellaneous, as outlined by Swindale and Bilinsky (2006). Each group counts towards the household score if one or more items from that group were consumed over the seven day period by any member of the household.

\subsection{Household level variables}

Household size, educational attainment and market access were included in the analyses in order to account for potential confounding impacts on the relationship between dietary quality and forest cover. These data were obtained from the IHS3 dataset and were selected based on findings from other studies. In this study, household size is a count of the number of individuals in each household. Education of the household head was used as a proxy for socio-economic status and was assessed using three indicators; school attendance, literacy in Chichewa and literacy in English. These indicators were set to a value of one if the household head had answered yes to attending school or being literate in either language, and zero otherwise. Access to markets was measured using three indicators; distance to the nearest road, distance to the nearest population 
centre ( $>20,000$ people), and distance to the nearest Agricultural Development and Marketing Corporation (ADMARC). Distance to the nearest ADMARC was the only variable representing an actual market which permits the sale and purchase of agricultural produce, whereas the other two variables were used as proxy indicators of market access in line with Ickowitz et al. (2013). The relationship between forest cover and all household level variables were also examined to assess whether forest cover is a significant determinant of household size, educational attainment and market access.

\subsection{Consumption of wild plant foods}

Despite wild foods only accounting for two out of 135 food items listed in the IHS3 dataset, wild food consumption was included in the analyses both as a predictor and response variable. Wild food consumption was included as a predictor in order to assess the contribution of wild foods to diet quality and was included as a response to assess whether consumption of these foods was affected by forest cover, market access, education and household size. In each case, the variable was dichotomous, where a value of one represented the consumption of one or both wild food types by a household, and a value of zero represented no wild food consumption. In addition, the contribution of wild foods to total household energy and vitamin A intake were quantified. The two foods listed as wild in the IHS3 were "wild fruit (masau, malambe etc.)" and "gathered wild green leaves". Given that "wild fruit" is likely to represent a number of different individual items (as suggested in the IHS3); it was matched with nutritional information for "wild fruit, average" in the Korkalo et al. (2011) FCT (99 kcal/100 g and $252 \mathrm{RAE} \mu \mathrm{g} / 100 \mathrm{~g}$ ). Similarly, "gathered green leaves" could refer to a number of different types of green leaves but this level of detail was not provided in the IHS3, thus nutritional information for "green leaves, raw, average" in the Korkalo et al. (2011) FCT were used as a best estimate ( $47 \mathrm{kcal} / 100 \mathrm{~g}$ and $267 \mathrm{RAE} \mu \mathrm{g} / 100 \mathrm{~g}$ ). The use of average nutrient values for wild foods in this study accounts for some of the variability that exists among individual wild food items. Moreover, given that no recent FCTs for Malawi exist, the use of the Mozambique FCT was felt to be reasonable, as there is evidence to suggest that the types and species of wild fruits and vegetables consumed in Malawi and Mozambique are similar (for example, see Korkalo et al. 2011 for the full list of wild food species sampled in Mozambique, as well as Magaia et al. 2013 and Maseko et al. 2017).

\subsection{Statistical analysis}

Means and proportions were calculated for all household level variables, as well as forest cover at the EA level. Percentage forest cover was calculated for each EA $(n=69)$ and all households were allocated a value for forest cover, meaning that households in the same EA shared the same value for percentage forest cover. For our main analysis, the data were modelled using general linear models, generalised linear models and generalised additive models. Each response variable was modelled separately, and the same general approach was used for each. All covariates were included into a maximal model and model simplification was carried out by manual backwards stepwise deletion of non-significant terms to produce a minimal sufficient model. All final models were examined for constancy of variance and normality of the model residuals, and if these were found to be unsatisfactory the model error family and/or link function were adjusted until the residuals were acceptable. In order to check for correlation between forest cover and the household level variables, simple linear regression models were used for market access, whereas binomial generalised linear models were used for educational attainment (as these were binary variables). All analyses were carried out using the language R (version 3.5.0; R Core Development Team).

\section{Results}

Calculated percentage forest cover and the number of households in each EA are summarised in Table 2. Descriptive statistics are reported at the household level $(n=2084)$ with the exception of forest cover which is at the EA level $(n=69)$ and mean energy and nutrient intakes which are measured across all individuals in our sample $(n=9396)$ (Table 3$)$. Mean dietary energy and iron adequacy were fairly high in the sample households ( $90.6 \%$ and $72.6 \%$, respectively); however there was a considerable amount of variation within the sample. Mean zinc and vitamin A adequacy were lower ( $40.2 \%$ and $40.3 \%$, respectively), again with considerable variation within the sample. School attendance was reported by $69.2 \%$ of household heads, whereas only $58.9 \%$ reported being able to read and write in Chichewa, and even fewer were literate in English (26.2\%). Furthermore, only around one sixth of households reported consuming wild foods (17.1\%).

Results from the multiple regressions are summarised in Table 4 . Forest cover was only a statistically significant predictor of vitamin A adequacy $(p=0.02)$. Household size was significantly negatively associated with all indicators of diet quality ( $p<0.001$ in each case) with the exception of dietary diversity score and wild food consumption. Educational attainment of the household head and access to markets were statistically significantly associated with some measures of diet quality. For example, dietary energy adequacy was negatively associated with distance to the nearest road $(p<0.001)$ and distance to the nearest ADMARC $(p=0.02)$, and positively associated with school attendance $(p=0.03)$ and English literacy $(p=$ $0.002)$. Iron adequacy was negatively associated with distance to the nearest road $(\mathrm{p}=0.002)$, while zinc and vitamin A adequacy were negatively associated with distance to the nearest 
Table 2 Dense, moderate, sparse and total forest cover in each enumeration area (EA) expressed as percentage of total land cover and the corresponding number of household in each area

\begin{tabular}{|c|c|c|c|c|c|}
\hline Enumeration area & Dense forest cover $(\%)$ & Moderate forest cover $(\%)$ & Sparse forest cover $(\%)$ & Total forest cover $(\%)$ & Number of households \\
\hline Bvumbwe & 1.97 & 2.59 & 23.75 & 28.32 & 12 \\
\hline Changata & 0.22 & 5.79 & 45.84 & 51.85 & 11 \\
\hline Chapananga & 0 & 2.29 & 43 & 45.29 & 39 \\
\hline Chigaru & 0 & 0.74 & 9.49 & 10.23 & 20 \\
\hline Chikowi & 0 & 1.08 & 11.84 & 12.92 & 18 \\
\hline Chikumbu & 0.05 & 1.67 & 14.31 & 16.04 & 21 \\
\hline Chimaliro & 1.07 & 4.22 & 16.09 & 21.38 & 31 \\
\hline Chimombo & 0 & 0.01 & 14.17 & 14.18 & 18 \\
\hline Chimwala & 0.69 & 1.52 & 20.4 & 22.61 & 16 \\
\hline Chitera & 0 & 0.17 & 8.46 & 8.63 & 9 \\
\hline Dambe & 0.39 & 5.17 & 13.02 & 18.58 & 52 \\
\hline Jalasi & 5.9 & 6.06 & 38.86 & 50.82 & 19 \\
\hline Kadewere & 0 & 0.1 & 6.43 & 6.54 & 49 \\
\hline Kalemebo & 0 & 0.18 & 13.53 & 13.71 & 75 \\
\hline Kanduku & 0 & 8.01 & 52.29 & 60.31 & 79 \\
\hline Kapeni & 0.16 & 0.71 & 5.78 & 6.65 & 22 \\
\hline Kapichi & 0.78 & 10.13 & 12.28 & 23.19 & 21 \\
\hline Kasisi & 0.06 & 0.28 & 56.33 & 56.66 & 10 \\
\hline Katuli & 3.28 & 5.36 & 23.61 & 32.25 & 9 \\
\hline Katunga & 0 & 0.22 & 29.28 & 29.5 & 8 \\
\hline Kawinga & 0.01 & 0.44 & 7.07 & 7.52 & 56 \\
\hline Kuntaja & 0.46 & 1.18 & 20.54 & 22.18 & 47 \\
\hline Kunthembule & 0 & 0.1 & 12.92 & 13.02 & 12 \\
\hline Kuntumanji & 0 & 0.22 & 5.1 & 5.33 & 29 \\
\hline Laston Njema & 4.85 & 8.77 & 23.23 & 36.84 & 28 \\
\hline Likoswe & 0.06 & 0.55 & 13.42 & 14.03 & 37 \\
\hline Liwonde & 0.01 & 0.23 & 24.98 & 25.22 & 41 \\
\hline Mabuka & 4.03 & 7.98 & 20.52 & 32.53 & 42 \\
\hline Machinjili & 0.01 & 0.26 & 8.86 & 9.13 & 11 \\
\hline Makanjila & 3.74 & 8.13 & 14.66 & 26.53 & 11 \\
\hline Makata & 0 & 0.1 & 2.51 & 2.61 & 9 \\
\hline Manikhwira & 0.24 & 0.6 & 26.07 & 26.91 & 25 \\
\hline Maseya & 0.14 & 0.05 & 62.94 & 63.13 & 10 \\
\hline Mlauli & 0 & 3.01 & 49.8 & 52.81 & 40 \\
\hline Mlolo & 0.38 & 1.15 & 30.83 & 32.37 & 51 \\
\hline Mlumbe & 0.26 & 0.58 & 12.07 & 12.92 & 35 \\
\hline Mnkhumba & 0.42 & 1.27 & 13.4 & 15.09 & 124 \\
\hline Mpama & 0.5 & 1.89 & 14.46 & 16.85 & 33 \\
\hline Mponda & 0.14 & 0.85 & 14.41 & 15.4 & 9 \\
\hline Mwabvi Game Reserve & 0 & 0.03 & 47.45 & 47.49 & 8 \\
\hline Mwambo & 0.03 & 0.2 & 8.58 & 8.81 & 37 \\
\hline Nankumba & 0.12 & 2.26 & 29.93 & 32.31 & 18 \\
\hline Nazombe & 0.22 & 1.61 & 17.01 & 18.84 & 54 \\
\hline Nchema & 0 & 0.01 & 4.69 & 4.69 & 26 \\
\hline Nchilamwela & 4.94 & 12.85 & 9.12 & 26.91 & 9 \\
\hline Ndamera & 0.03 & 0.58 & 39.51 & 40.12 & 15 \\
\hline Ngabu & 0 & 0.19 & 25.67 & 25.86 & 69 \\
\hline Nkalo & 0.01 & 0.37 & 10.4 & 10.78 & 32 \\
\hline
\end{tabular}


Table 2 (continued)

\begin{tabular}{|c|c|c|c|c|c|}
\hline Enumeration area & Dense forest cover $(\%)$ & Moderate forest cover $(\%)$ & Sparse forest cover $(\%)$ & Total forest cover $(\%)$ & Number of households \\
\hline Nkanda & 0 & 0.07 & 17.91 & 17.98 & 30 \\
\hline Nsabwe & 2.67 & 7.29 & 56.41 & 66.37 & 10 \\
\hline Nsamala & 0 & 0.08 & 11.92 & 12.01 & 92 \\
\hline Nthache & 0 & 10.48 & 55.22 & 65.7 & 94 \\
\hline Nthiramanja & 0 & 0.65 & 9.21 & 9.85 & 10 \\
\hline Nyambi & 2.55 & 2.39 & 33 & 37.94 & 12 \\
\hline S/C Chamba & 4.28 & 13.53 & 35.08 & 52.9 & 11 \\
\hline S/C Chikweo & 0.01 & 0.11 & 19.83 & 19.95 & 30 \\
\hline S/C Chiwalo & 0.04 & 0.56 & 23.59 & 24.19 & 9 \\
\hline S/C Chowe & 1.47 & 1.52 & 35.4 & 38.39 & 30 \\
\hline S/C Jumba & 0 & 0.01 & 11.53 & 11.54 & 26 \\
\hline S/C Kwethemule & 1.96 & 7.97 & 51.83 & 61.75 & 11 \\
\hline S/C Mbenje & 0 & 0.01 & 16.94 & 16.95 & 42 \\
\hline S/C Mbiza & 0 & 0.13 & 5.32 & 5.45 & 27 \\
\hline S/C Mphuka & 1.48 & 6.6 & 66.81 & 74.89 & 8 \\
\hline S/C Mposa & 2.73 & 4.82 & 18.38 & 25.93 & 11 \\
\hline S/C Sitola & 3.93 & 9.65 & 35.82 & 49.39 & 10 \\
\hline S/C Thukuta & 0 & 0.32 & 68.56 & 68.88 & 9 \\
\hline Somba & 0.07 & 1.56 & 58.07 & 59.7 & 46 \\
\hline Symon & 0 & 0.25 & 18.45 & 18.69 & 82 \\
\hline Tengani & 0.03 & 0.47 & 36.84 & 37.33835 & 27 \\
\hline
\end{tabular}

population centre $(p=0.02$ and $p=0.002$, respectively). Lastly, dietary diversity score was negatively associated with distance to the nearest road and positively associated with literacy in Chichewa and English ( $p<0.001$ in each case).

When wild food consumption was modelled as a response variable, it was positively associated with distance to the nearest ADMARC $(p=0.001)$ and school attendance $(p=0.05)$, and negatively associated with Chichewa literacy $(p=0006)$. Similarly, we found that average vitamin A intake was $54 \%$ higher in households who consumed one or both of the wild food items compared to households that consumed neither (418 $\mathrm{RAE} \mu \mathrm{g} /$ day and $272 \mathrm{RAE} \mu \mathrm{g} /$ day, respectively). Lastly, households in EAs with high forest cover were significantly less likely to have attended school and be literate in English than households in low forest cover areas. Likewise, distances to the nearest population centres and ADMARCs were significantly higher for households in high forest cover EAs compared to households in lower forest cover EAs ( $p<0.001$ in all cases).

\section{Discussion}

\subsection{The relationship between diet quality and forest cover}

The aim of this study was to examine the relationship between forest cover and diet quality in rural southern Malawi. Forest cover was only significantly associated with vitamin A adequacy. This relationship between vitamin A intake and forest cover is consistent with results from previous studies (Boedecker et al. 2014; Fungo et al. 2016; Galway et al. 2018; Ickowitz et al. 2013; Ickowitz et al. 2016). Wild food consumption was also positively associated with vitamin A adequacy, but not with forest cover. This suggests that households in high forest cover areas were no more likely to eat wild foods than households in low forest cover areas. As a consequence, the improved vitamin A adequacy of households in the most forested EAs cannot be directly attributed to wild food consumption. This could be explained by the fact that not all wild foods are sourced from forests (Powell et al. 2015). For example, Powell et al. (2011) found that in an agricultural community in Tanzania, only $12 \%$ of wild foods were sourced from forests compared to $62 \%$ from farmland. Therefore, the wild foods reported in the IHS3 dataset may have been gathered from other natural environments and not just forests. Regardless of where they were sourced from, households who reported consuming wild foods had a substantially higher (54\%) average vitamin A intake than households who did not consume them, which is unsurprising due to their very high vitamin A content (Korkalo et al. 2011). This is consistent with other studies and highlights the potential role of wild foods in tackling micronutrient deficiencies (Ickowitz et al. 2016; Johnson et al. 2013). It is also possible that these foods were sourced from forests, but the sample size of 
households who consumed wild foods $(n=355)$ was too small to establish a relationship with forest cover in this study. The absence of a significant relationship between forest cover and wild food consumption suggests that households in the most forested EAs were obtaining vitamin A from another source. If households were not directly consuming forest foods, they may still have benefitted nutritionally via a number of indirect pathways (Heubach et al. 2011; Hickey et al. 2016; Ickowitz et al. 2016; Reed et al. 2017).

The fact that forest cover was not a significant determinant of any other aspect of dietary adequacy or dietary diversity score is inconsistent with previous studies of Malawi and other similar countries (Ickowitz et al. 2013; Ickowitz et al. 2016; Maseko et al. 2017; Rowland et al. 2016), but is consistent with findings by Termote et al. (2012). Termote et al. (2012) attributed their findings mainly to a lack of knowledge of wild foods and their potential nutritional benefits, and also to the workload involved in collecting and preparing wild foods. These may also be factors in this study. Similarly, wild foods are sometimes rejected by households as they are associated with low social status, whereas foods that can be purchased are perceived as a sign of affluence (Cruz et al. 2014). Therefore, the availability of wild foods does not always guarantee their consumption. Furthermore, if households in the most forested EAs used forest products as an income source rather than for direct consumption, the nutritional benefits may be missed if the income generated was not used to buy equally varied and nutritious foods.

While forest cover was only a significant determinant of vitamin A adequacy, a number of significant relationships were found between household level variables and diet quality. In line with our hypothesis, households with larger family sizes were found to have less adequate diets. However, no relationship was found between household size and dietary diversity score, which was inconsistent with findings from other studies (Koppmair et al. 2016; Powell et al. 2017). Powell et al. (2017) posit that although a larger family size increases pressure on resources and adults in a household, in some cases it may increase dietary diversity because acquiring a large amount of one food type to feed a large family is more difficult than getting smaller amounts of many different food types, leading to a wider range of foods consumed by the
Table 3 Summary statistics of variables used in regressions. Note: individual consumption was not used in any analysis and is only included in this table for comparison with findings from other studies

\begin{tabular}{|c|c|c|}
\hline Dependent variables & $\mathrm{n}$ & Mean (SD) or \% \\
\hline Dietary energy consumption per capita (kcals/day) & 9396 & $1745.9(1006)$ \\
\hline Dietary energy adequacy $(\%)$ & 2084 & $90.6(40.6)$ \\
\hline Iron intake per capita (mg/day) & 9396 & $19.5(12.5)$ \\
\hline Iron adequacy $(\%)$ & 2084 & $72.6(45.8)$ \\
\hline Zinc intake per capita (mg/day) & 9396 & $3.1(3.3)$ \\
\hline Zinc adequacy $(\%)$ & 2084 & $40.2(45.3)$ \\
\hline Vitamin A intake per capita (RAE $\mu \mathrm{g} /$ day) & 9396 & $188.9(288.4)$ \\
\hline Vitamin A adequacy $(\%)$ & 2084 & $40.3(54.7)$ \\
\hline Diet diversity score (HDDS) & 2084 & $7.8(2)$ \\
\hline \multicolumn{3}{|l|}{ Independent variables } \\
\hline Forest cover $(\%)$ & 69 & $29.1(19.9)$ \\
\hline Household size & 2084 & $4.4(1.9)$ \\
\hline School attendance & 2084 & \\
\hline Yes & & 69.2 \\
\hline No & & 30.8 \\
\hline Literate in Chichewa & 2084 & \\
\hline Yes & & 58.9 \\
\hline No & & 41.1 \\
\hline Literate in English & 2084 & \\
\hline Yes & & 26.2 \\
\hline No & & 73.8 \\
\hline Distance to the nearest road $(\mathrm{km})$ & 2084 & $12.8(12.4)$ \\
\hline Distance to the nearest population centre $(>20,000)(\mathrm{km})$ & 2084 & $39.2(19.1)$ \\
\hline Distance to the nearest ADMARC (km) & 2084 & $7.9(5.1)$ \\
\hline Wild foods consumed & 2084 & \\
\hline Yes & & 17.1 \\
\hline No & & 82.9 \\
\hline
\end{tabular}


household. Similarly, educational attainment of the household head was positively associated with dietary energy adequacy and dietary diversity score (but no relationship was found with micronutrient intake). This is consistent with a number of other studies which found that better educated households have improved dietary outcomes (Fungo et al. 2016; Ickowitz et al. 2013; Jones et al. 2014; Snapp and Fisher 2015). However, it is unclear why micronutrient adequacy was unaffected by educational attainment. The negative association between Chichewa literacy and wild food consumption is consistent with other studies that relate increased consumption of wild foods to lower education levels (Fungo et al. 2016; Kuhnlein et al. 2006). It is possible that illiterate households have lower income and may be more reliant on foods from the wild than more affluent households. Furthermore, the reason for the negative relationship between educational attainment and forest cover is not clear; however, there is considerable evidence to suggest that incomes are lower in forest communities than in other areas (Fisher and Christopher 2007; Sunderlin et al. 2008), so educational attainment could be related to the lower income of people living in forested areas. Lastly, our findings relating to market access were consistent with our hypothesis, and other studies that found households further from markets have poorer diet quality (Ickowitz et al. 2013; Koppmair et al. 2016; Sibhatu et al. 2015; Snapp and Fisher 2015). Similarly, households with longer distances to the nearest ADMARC were more likely to consume wild foods, indicating a reliance on these foods when agricultural markets are less accessible. This is consistent with a recent study by Chaves et al. (2017) that found rural communities with better market access consumed less wild meat than those with poorer market access in central Amazonia, Brazil.

\subsection{Limitations}

This study has a number of important limitations that should be considered when interpreting the results. As forest cover was calculated at the EA level, we cannot account for the proximity of individual households to forests, nor do we have any information regarding accessibility. Thus, it was assumed that all households in an EA would benefit equally from the forest areas and the resources/services they provide. This may also differ depending on EA size which we have not accounted for. Given that we cannot account for differences in household proximity to forests within the EAs, we may be underestimating the importance of forests for households closest to them. The assumption that all forests are accessible (i.e. do not have restrictions due to conservation) is felt to be reasonable as $63 \%$ of forests in Malawi are classed as customary land by the FAO (2010). Likewise, our data did not distinguish between types of forest (i.e. native versus agro-forests) and we assume that all forest land is "natural" and valuable in terms of forest foods. This is felt to be a reasonable assumption given that $88 \%$ of forest land in Malawi is considered "natural" according to the Global Forest Resources Assessment (FAO 2010).

There were limitations of using the IHS3 dataset to examine wild food consumption as there was no category in the

Table 4 Results of multiple regression models between forest cover and household level variables with indicators of diet quality and wild food consumption

\begin{tabular}{|c|c|c|c|c|c|c|}
\hline Type of model & $\begin{array}{l}\text { Dietary energy } \\
\text { adequacy } \\
\text { Gamma GLM }\end{array}$ & $\begin{array}{l}\text { Iron adequacy } \\
\text { Gamma GLM }\end{array}$ & $\begin{array}{l}\text { Zinc adequacy } \\
\text { Inverse Gaussian } \\
\text { GAM }\end{array}$ & $\begin{array}{l}\text { Vitamin A } \\
\text { adequacy } \\
\text { Gamma GLM }\end{array}$ & $\begin{array}{l}\text { Diet diversity } \\
\text { score } \\
\text { Poisson GLM }\end{array}$ & $\begin{array}{l}\text { Wild food } \\
\text { consumption } \\
\text { Binomial GLM }\end{array}$ \\
\hline Forest cover & NS & NS & NS & $0.003(2.27)^{*}$ & NS & NS \\
\hline Household size & $\begin{array}{l}-0.102 \\
\quad(-19.25)^{* * * *}\end{array}$ & $\begin{array}{l}-0.18 \\
\quad(-20.65) * * *\end{array}$ & $-7.08(-472.6) * * *$ & $-0.1(-6.97)^{* * *}$ & NS & NS \\
\hline School attendance & $0.048(2.06) *$ & NS & NS & NS & NS & $0.33(2.02)^{*}$ \\
\hline Chichewa literacy & NS & NS & NS & NS & $0.12(6.501)^{* * *}$ & $\begin{array}{l}-0.43 \\
\quad(-2.82) * *\end{array}$ \\
\hline English literacy & $0.07(3.05)^{* *}$ & NS & NS & NS & $0.087(4.38)^{* * *}$ & NS \\
\hline Distance to the nearest road & $\begin{array}{l}-0.003 \\
\quad(-3.78) * * *\end{array}$ & $-0.004(-3.14)^{* *}$ & NS & NS & $\begin{array}{l}-0.003 \\
\quad(-4.81) * * *\end{array}$ & NS \\
\hline $\begin{array}{l}\text { Distance to the nearest } \\
\text { population centre }\end{array}$ & NS & NS & $-1.004(-6.43)^{*}$ & $\begin{array}{l}-0.005 \\
\quad(-3.09) * *\end{array}$ & NS & NS \\
\hline $\begin{array}{l}\text { Distance to the nearest } \\
\text { ADMARC }\end{array}$ & $\begin{array}{l}-0.004 \\
\quad(-2.29)^{*}\end{array}$ & NS & NS & NS & NS & $\begin{array}{l}0.032 \\
\quad(3.37)^{* * *}\end{array}$ \\
\hline Wild food consumption & NS & NS & NS & $0.401(5.36)^{* * *}$ & NS & $\mathrm{n} / \mathrm{a}$ \\
\hline
\end{tabular}

${ }^{\mathrm{a}}$ Values are model coefficients with test statistics in parentheses.

$\mathrm{b} * p<0.05 ; * * p<0.01 ; * * * p<0.001$.

${ }^{\mathrm{c}}$ The significance levels indicated are those for the parameters retained in the final models. "NS" denotes not significant 
questionnaire for households to report food as being gathered from the wild. Rather, households could choose from "own production" or "purchased", thus, the majority of households left these columns blank, or classed the wild foods as being from their own production. Thus, other items listed in the IHS 3 could have been gathered from the wild but were not listed as such - potentially leading to the under-reporting of wild food consumption. This seems particularly likely given that no wild animal source foods were reported in the survey. Likewise, we could not ascertain if the reported wild foods were collected from forests or other natural environments as this level of detail was not provided in the IHS3. Seasonality may also have played a role in wild food availability but as the IHS3 was conducted over the course of one year (and households were surveyed at different times), seasonality was not accounted for in this study. Moreover, the use of average nutrient values for the two wild food items (from the Korkalo et al. 2011 tables) may over- or under- estimate household vitamin A intake. As we were unable to ascertain exactly which wild food items were included in the "wild fruit" and "gathered green leaves" categories, the use of average values was a best estimate, but this should be noted when interpreting the results. It should also be noted that there is a lack of available nutrient composition data for wild foods in general, and further research is required to increase the understanding of these foods, and their nutritional potential in countries such as Malawi.

Furthermore, the HDDS was originally validated for use on $24 \mathrm{~h}$ dietary recall data; whereas we used a modified version which counts the number of food groups consumed over seven days. Other studies have used the HDDS on seven day data (Jones et al. 2014), but the associated limitations should be noted. For example, a longer recall period is likely to result in less accurate reporting of foods consumed over the duration (Swindale and Bilinsky 2006). On the other hand, recording food consumption over seven days is more likely to include all foods routinely eaten by the household which could be missed using a $24 \mathrm{~h}$ recall.

Assessing market access using simple indicators of proximity does not capture the specific and complex nature of market participation (Jones 2016). Therefore, a key assumption of our study is that households with shorter distances to markets are also able to participate (socially and economically) in buying and selling activities. Lastly, although we have controlled for a number of social and demographic variables likely to be associated with diet quality and forest cover, the reliance on observational data means we cannot ascertain the potentially numerous other variables likely to confound the relationship between forests and diet quality. Further research is needed to establish causal pathways for the demonstrated associations between diet quality and forest cover.

\section{Conclusions}

This study has found that in rural southern Malawi, households located in more forested areas have improved vitamin A intake compared to households in areas with less forest cover. This is supportive of a wider literature that has found biodiverse landscapes to be beneficial for some aspects of diet quality. Although not linked to forest cover in this study, consumption of wild plant foods was also highly beneficial for vitamin A intake, as households that reported consuming them had on average a 54\% higher intake than households that did not consume them. On the other hand, forest cover was not a significant determinant of any other measure of diet quality in this study, which was surprising (particularly for dietary diversity) given the results of previous studies. Household size, education and market access were significant determinants of diet quality in varying degrees. It is possible that household diets were more affected by these sociodemographic factors than forest cover in our study. Further research is required to elucidate these associations in Malawi, not only for improving diets and establishing causal pathways for the demonstrated associations between diet quality and forest cover, but also for ensuring forest conservation and preventing the loss of critical ecosystem services.

\section{Compliance with ethical standards}

Conflict of interest No potential conflict of interest was reported by the authors.

Open Access This article is distributed under the terms of the Creative Commons Attribution 4.0 International License (http:// creativecommons.org/licenses/by/4.0/), which permits unrestricted use, distribution, and reproduction in any medium, provided you give appropriate credit to the original author(s) and the source, provide a link to the Creative Commons license, and indicate if changes were made.

\section{References}

Aberman, N.L., Meerman, J. \& Benson, T. (2018). Agriculture, food security and nutrition in Malawi. International food policy research institute, Washington DC. http://ebrary.ifpri.org/cdm/ref/collection/ p15738coll2/id/132311. Accessed 10th July 2018.

Aerts, R., \& Honnay, O. (2011). Forest restoration, biodiversity and ecosystem functioning. BMC Ecology, 11-29.

Ahenkan, A., \& Boon, E. (2011). Non-timber forest products (NTFPs): Clearing the confusion in semantics. Journal of Human Ecology, $33(1), 1-9$.

Angelsen, A., Jagger, P., Babigumira, R., Belcher, B., Hogarth, N. J., Bauch, S., et al. (2014). Environmental income and rural livelihoods: A global-comparative analysis. World Development, 64(1), $12-28$. 
Arimond, M., \& Ruel, M. T. (2004). Dietary diversity is associated with child nutritional status: Evidence from 11 demographic and health surveys. The Journal of Nutrition, 134(10), 2579-2585.

Arnold, M., Powell, B., Shanley, P., \& Sunderland, T. C. H. (2011). Forests, biodiversity and food security. International Forestry Review, 13(3), 259-264.

Austin, K. G., Gonzalez-Roglich, M., Schaffer-Smith, D., Schwantes, A. M., \& Swenson, J. J. (2017). Trends in size of tropical deforestation events signal increasing dominance of industrial-scale drivers. Environmental Research Letters, 12(5).

Baudron, F., Chavarria, J. Y. D., Remans, R., Yang, K., \& Sunderland, T. (2017). Indirect contributions of forests to dietary diversity in southern Ethiopia. Ecology and Society, 22(2), 28.

Belcher, B., Ruiz-Perez, M., \& Achdiawan, R. (2005). Global patterns and trends in the use and management of commercial NTFPs: Implications for livelihood and conservation. World Development, 33(9), 1435-1452.

Bermudez, O. I., Lividini, K., Smitz, M. F., \& Fiedler, J. L. (2012). Estimating micronutrient intakes from household consumption and expenditure surveys (HCES): An example from Bangladesh. Food and Nutrition Bulletin, 33(3), 208-213.

Bharucha, Z., \& Pretty, J. (2010). The roles and values of wild foods in agricultural systems. Philosophical Transactions of the Royal Society B: Biological Sciences, 365(1554), 2913-2926.

Bone, R. A., Parks, K. E., Hudson, M. D., Tsirinzeni, M., \& Willcock, S. (2017). Deforestation since independence: A quantitative assessment of four decades of land-cover change in Malawi. Southern Forests: a Journal of Forest Science, 79(4), 269-275.

Boedecker, J., Termote, C., Assogbadjo, A. E., Van Damme, P., \& Lachat, C. (2014). Dietary contribution of Wild Edible Plants to women's diets in the buffer zone around the Lama forest, Benin-an underutilized potential. Food Security, 6(6), 833-849. https://doi. org/10.1007/s12571-014-0396-7

Broegaard, R. B., Rasmussen, L. V., Dawson, N., Mertz, O., Vongvisouk, T., \& Grogan, K. (2017). Wild food collection and nutrition under commercial agriculture expansion in agriculture-forest landscapes. Food Policy and Economics, 84, 92-101.

Brown, M. E., Grace, K., Shively, G., Johnson, K. B., \& Carroll, M. (2014). Using satellite remote sensing and household survey data to assess human health and nutrition response to environmental change. Population and Environment, 36(1), 48-72.

Chappell, M. J., \& LaVelle, L. A. (2009). Food security and biodiversity: Can we have both? An agroecological analysis. Agriculture and Human Values, 28(1), 3-26.

Chaves, W. A., Wilkie, D. S., Monroe, M. C., \& Sieving, K. E. (2017). Market access and wild meat consumption in the Central Amazon, Brazil. Biological Conservation, 212(Part A), 240-248.

Colfer, C. J. P., Sheil, D., Kaimowitz, D., \& Kishi, M. (2006). Forests and human health in the tropics: Some important connections. Unasylva, 57(224), 3-10.

Cruz, P. M., Medeiros, P. M., Combariza, I. S., Peroni, N., \& Albuquerque, P. (2014). "I eat the manofê so it is not forgotten": Local perceptions and consumption of native wild edible plants from seasonal dry forests in Brazil. Journal of Ethnobiology and Ethnomedicine, 10(45), 45.

D’Annunzio, R., Sandker, M., Finegold, Y., \& Min, Z. (2015). Projecting global forest area towards 2030. Forest Ecology and Management, $352,124-133$.

Dobbie, S.L. (2016). The potential of agent-based modelling as a tool to unravel the complexity of household food security: A case study of rural southern Malawi. Unpublished doctoral thesis, University of Southampton. https://eprints.soton.ac.uk/412710/1/FINAL_e thesis_for_e prints_DOBBIE_25698656.pdf. Accessed 10th July 2018.

FAO (2001). Human energy requirements. Report of a Joint FAO/WHO/ UNU Expert Consultation. The Food and Agriculture Organization of the United Nations, Rome. http://www.fao.org/docrep/007/ y5686e/y5686e00.htm. Accessed 16th November 2017.

FAO (2010). Global Forest Resources Assessment 2010. FAO Forestry Paper No. 163. The Food and Agriculture Organization of the United Nations, Rome. http://www.fao.org/docrep/013/i1757e/ i1757e.pdf. Accessed 16th November 2017.

FAO (2013). Towards food security and improved nutrition: Increasing the contribution of trees and forests. The Food and Agriculture Organization of the United Nations, Rome. http://www.fao.org/ docrep/018/i2969e/i2969e.pdf. Accessed 1st July 2018.

FAO (2015). The State of Food Insecurity in the World. Meeting the 2015 international hunger targets: taking stock of uneven progress. The Food and Agriculture Organization of the United Nations, Rome. http://www.fao.org/3/a-i4646e.pdf. Accessed 23rd November 2017.

FAO, IFAD, UNICEF, WFP and WHO. (2018). The State of Food Security and Nutrition in the World 2018. Building climate resilience for food security and nutrition. Food and Agriculture Organisation of the United Nations, Rome. Available online: http://www.fao.org/state-of-food-security-nutrition/en/

Fisher, B., \& Christopher, T. (2007). Poverty and biodiversity: Measuring the overlap of human poverty and the biodiversity hotspots. Ecological Economics, 62(1), 93-101.

Fisher, M., Chaudhury, M., \& McCusker, B. (2010). Do forests help rural households adapt to climate variability? Evidence from southern Malawi. World Development, 38(9), 1241-1250.

Foley, J. A., Ramankutty, N., Brauman, K. A., Cassidy, E. S., Gerber, J. S., Johnston, M., et al. (2011). Solutions for a cultivated planet. Nature, 478, 337-342.

Foli, S., Reed, J., Clendenning, J., Petrokofsky, G., Padoch, C., \& Sunderland, T. (2014). To what extent does the presence of forests and trees contribute to food production in humid and dry forest landscapes?: A systematic review protocol. Environmental Evidence, 3, 15.

Fungo, R., Muyonga, J., Kabahenda, M., Kaaya, A., Okia, C. A., Donn, P., et al. (2016). Contribution of forest foods to dietary intake and their association with household food insecurity: A cross-sectional study in women from rural Cameroon. Public Health Nutrition, 19(17), 3185-3196.

Galway, L. P., Acharya, Y., \& Jones, A. D. (2018). Deforestation and child diet diversity: A geospatial analysis of 15 sub-Saharan African countries. Health and Place, 51, 78-88.

Hansen, M. C., Potapov, P. V., Moore, R., Hancher, M., Turubanova, S. A., Tyukavina, A., et al. (2013). High-resolution global maps of 21st-century forest cover change. Science, 342, 850-853.

Harris, F. M. A., \& Mohammed, S. (2003). Relying on nature: Wild foods in northern Nigeria. Ambio: A Journal of the Human Environment, 32(1), 24-29.

Hatloy, A., Torheim, L. E., \& Oshaug, A. (1998). Food variety-a good indicator of nutritional adequacy of the diet? A case study from an urban area in Mali, West Africa. European Journal of Clinical Nutrition, 52(12), 891-898.

Heubach, K., Wittig, R., Nuppenau, E. A., \& Hahn, K. (2011). The economic importance of non-timber forest products (NTFPs) for livelihood maintenance of rural west African communities: A case study from northern Benin. Ecological Economics, 70(11), 19912001.

Hickey, G. M., Pouliot, M., Smith-Hall, C., Wunder, S., \& Nielsen, S. R. (2016). Quantifying the economic contribution of wild food harvests to rural livelihoods: A global-comparative analysis. Food Policy, 62, $122-132$.

Hosonuma, N., Herold, M., De Sy, V., De Fries, R. S., Brockhaus, M., Verchot, L., et al. (2012). An assessment of deforestation and forest degradation drivers in developing countries. Environmental Research Letters, 7(4). 
Ickowitz, A., Powell, B., Salim, M. A., \& Sunderland, T. C. H. (2013). Dietary quality and tree cover in Africa. Global Environmental Change, 24, 287-294.

Ickowitz, A., Rowland, D., Powell, B., Salim, M. A., \& Sunderland, T. (2016). Forests, trees, and micronutrient-rich food consumption in Indonesia. PLoS One, 11(5), e0154139.

IOM (2001). DRI Dietary Reference Intakes. Applications in Dietary Assessment. A Report of the Subcommittee on Interpretation and Uses of Dietary Reference Intakes and the Standing Committee on the Scientific Evaluation of Dietary Reference Intakes. Food and Nutrition Board, Institute of Medicine. Washington, D.C: National Academy Press.

Johnson, K. B., Jacob, A., \& Brown, M. E. (2013). Forest cover associated with improved child health and nutrition: Evidence from the Malawi demographic and health survey and satellite data. Global Health: Science and Practice, 1(2), 237-248.

Jones, A. D. (2016). On-farm crop species richness is associated with household diet diversity and quality in subsistence- and marketoriented farming households in Malawi. The Journal of Nutrition, 147(1), 86-96.

Jones, A. D. (2017). Critical review of the emerging research evidence on agricultural biodiversity, diet diversity, and nutritional status in lowand middle-income countries. Nutrition Reviews, 75(10), 769-782.

Jones, A. D., Shrinivas, A., \& Bezner-Kerr, R. (2014). Farm production diversity is associated with greater household dietary diversity in Malawi: Findings from nationally representative data. Food Policy, $46,1-12$.

Joy, E. J. M., Kumssa, D. B., Broadley, M. R., Watts, M. J., Young, S. D., Chilimba, A. D. C., \& Ander, L. (2015). Dietary mineral supplies in Malawi: Spatial and socioeconomic assessment. BMC Nutrition, 1(1), 1-42.

Kamanga, P., Vedeld, P., \& Sjaastad, E. (2009). Forest incomes and rural livelihoods in Chiradzulu district, Malawi. Ecological Economics, 68(3), 613-624.

Koppmair, S., Kassie, M., \& Qaim, M. (2016). Farm production, market access and dietary diversity in Malawi. Public Health Nutrition, 20(2), 325-335.

Korkalo, L., Hauta-alus, H. \& Mutanen, M. (2011). Food composition tables for Mozambique. Version 2. Department of Food and Environmental Sciences. University of Helsinki, Finland. http:// www.helsinki.fi/food-and-environment/research/groups/Food composition tables for Mozambique.pdf. Accessed 22nd November 2017

Kuhnlein, H., Erasmus, B., Creed-Kanashiro, H., Englberger, L., Okeke, C., Turner, N., Allen, L., \& Bhattacharjee, L. (2006). Indigenous peoples' food systems for health: Finding interventions that work. Public Health Nutrition, 9(8), 1013-1019.

Lanz, B., Dietz, S. \& Swanson, T. (2017). The expansion of modern agriculture and global biodiversity decline: An integrated assessment. Grantham research institute. Working paper 167. http:// www.lse.ac.uk/GranthamInstitute/wp-content/uploads/2016/06/ Working-Paper-167-Lanz-et-al-May-2017-update-1.pdf. Accessed 4th December 2017.

Magaia, T., Uamusse, A., Sjoholm, I. \& Skog, K. (2013). Proximate analysis of five wild fruits of Mozambique. The Scientific World Journal, Article ID 601435

Manary, M. J., Hotz, C., Krebs, N. F., Gibson, R. S., Westcott, J. E., Arnold, T., Broadhead, R. L., \& Hambidge, K. M. (2000). Dietary phytate reduction improves zinc absorption in Malawian children recovering from tuberculosis but not in well children. Journal of Nutrition, 130(12), 2959-2964.

Maseko, H., Shakleton, C. M., Nagoli, J., \& Pullanikkatil, D. (2017). Children and wild foods in the context of deforestation in rural Malawi. Human Ecology, 45(6), 795-807.

Mwase, W. F., Bjørnstad, A., Bokosi, J. M., Kwapata, M. B., \& Stedje, B. (2007). The role of land tenure in conservation of tree and shrub species diversity in miombo woodlands of southern Malawi. New Forests, 33(3), 297-307.

Naser, I. A., Jalil, R., Wan Muda, W. M., Wan Nik, W. S., Shariff, Z. M., \& Abdullah, M. R. (2014). Association between household food insecurity and nutritional outcomes among children in northeastern of peninsular Malaysia. Nutrition Research and Practice, 8(3), 304-311.

NSO (2017). Malawi Micronutrient Survey 2015-16: Key Indicators Report. Zomba, Malawi: National Statistical Office. https:// dhsprogram.com/pubs/pdf/FR319/FR319m.pdf. Accessed 8th December 2017.

Palmer, C., \& Di Falco, S. (2012). Biodiversity, poverty and development. Oxford Review of Economic Policy, 28(1), 48-68.

Pei, C. S., Appannah, G., \& Sulaiman, N. (2018). Household food insecurity, diet quality, and weight status among indigenous women (Mah Meri) in peninsular Malaysia. Nutrition Research and Practice, 12(2), 135-142.

Pfund, J. L., Watts, J. D., Biossiere, M., Boucard, A., Bullock, R. M., Ekadinata, A., et al. (2011). Understanding and integrating local perceptions of trees and forests into incentives for sustainable landscape management. Environmental Management, 48(2), 334-349.

Phalan, B., Onial, M., Balmford, A., \& Green, R. E. (2011). Reconciling food production and biodiversity conservation: Land sharing and land sparing compared. Science, 333(6047), 1289-1291.

Pimentel, D., McNair, M., Buck, L., Pimentel, M., \& Kamil, J. (1997). The value of forests to world food security. Human Ecology, 25(1), 91-120.

Poppy, G. M., Chiotha, S., Eigenbrod, F., Harvey, C. A., Honzak, M., Hudson, M. D., et al. (2014). Food security in a perfect storm: Using the ecosystem services framework to increase understanding. Philosophical Transactions of the Royal Society B, Biological Sciences, 369(1639), 20120288.

Powell, B., Hall, J., \& Johns, T. (2011). Forest cover, use and dietary intake in the east Usambara Mountains, Tanzania. International Forestry Review, 13(3), 305-317.

Powell, B., Thilsted, S. H., Ickowitz, A., Termote, C., Sunderland, T., \& Herforth, A. (2015). Improving diets with wild and cultivated biodiversity from across the landscape. Food Security, 7(3), 535-554.

Powell, B., Kerr, R. B., Young, S. L., \& Johns, T. (2017). The determinants of dietary diversity and nutrition: Ethnonutrition knowledge of local people in the east Usambara Mountains, Tanzania. Journal of Ethnobiology and Ethnomedicine, 13(1), 23.

Rah, J. H., Akhter, N., Semba, R. D., de Pee, S., Bloem, M. W., Campbell, A. A., et al. (2010). Low dietary diversity is a predictor of child stunting in rural Bangladesh. European Journal of Clinical Nutrition, 64(12), 1393-1398.

Reed, J., van Vianen, J., Foli, S., Clendenning, J., Yang, K., MacDonald, M., et al. (2017). Trees for life: The ecosystem service contribution of trees to food production and livelihoods in the tropics. Food Policy and Economics, 84, 62-71.

Rowland, D., Ickowitz, A., Powell, B., Nasi, R., \& Sunderland, T. (2016). Forest foods and healthy diets: Quantifying the contributions. Environmental Conservation, 44(2), 102-114.

Sandifer, P. A., Sutton-Grier, A. E., \& Ward, B. P. (2015). Exploring connections among nature, biodiversity, ecosystem services, and human health and well-being: Opportunities to enhance health and biodiversity conservation. Ecosystem Services, 12, 1-15.

Schaafsma, M., Morse-Jones, S., Posen, P., Swetnam, R. D., Balmford, A., Bateman, I. J., et al. (2014). The importance of local forest benefits: Economic valuation of non-timber forest products in the eastern Arc Mountains in Tanzania. Global Environmental Change, 24(1), 295-305.

Shakleton, C. M., \& Shakleton, S. E. (2004). The importance of nontimber forest products in rural livelihood security and as safety nets: A review of evidence from South Africa. South African Journal of Science, 100(11-12), 658-664. 
Shakleton, C. M., Shakleton, S. E., Buiten, E., \& Bird, N. (2007). The importance of dry woodlands and forests in rural livelihoods and poverty alleviation in South Africa. Forest Policy and Economics, 9(5), 558-577.

Sibhatu, K. T., Krishna, V. V., \& Qaim, M. (2015). Production diversity and dietary diversity in smallholder farm households. PNAS, $112(34), 10657-10662$.

Snapp, S. S., \& Fisher, M. (2015). "Filling the maize basket" supports crop diversity and quality of household diet in Malawi. Food Security, 7(1), 83-96.

Stadlmayr, B., Charrondiere, R., Enujiugha, V., Bayili, R., Fagbohoun, E., Samb, B., et al. (2012). West African food composition table. Food and agriculture Organization of the United Nations, Rome. http://www.fao.org/docrep/015/i2698b/i2698b00.pdf. Accessed 1st November 2017.

Steyn, N. P., Nel, J. H., Nantel, G., Kennedy, G., \& Labadarios, D. (2006). Food variety and dietary diversity scores in children: Are they good indicators of dietary adequacy? Public Health Nutrition, 9(5), 644 650 .

Sunderlin, W. D., Dewi, S., Puntodewo, A., Muller, D., Angelsen, A., \& Epprecht, M. (2008). Why forests are important for global poverty alleviation: A spatial explanation. Ecology and Society, 13(2), 24.

Swindale, A. \& Bilinsky, P. (2006). Household dietary diversity score (HDDS) for measurement of household food access: Indicator guide (v.2). Washington, D.C. https://www.fantaproject.org/monitoringand-evaluation/household-dietary-diversity-score. Accessed 23 October 2017.

Termote, C., Meyi, M. B., Djailo, B. D., Huybregts, L., Lachat, C., Kolsteren, P., et al. (2012). A biodiverse rich environment does not contribute to a better diet: A case study from DR Congo. PLoS One, 7(1), e30533.

Turner, N. J., Luczaj, L. J., Migliorini, P., Pieroni, A., Dreon, A. L., Sacchetti, L. E., et al. (2011). Edible and tended wild plants, traditional ecological knowledge and agroecology. Critical Reviews in Plant Sciences, 30, 198-225.

UN (2011). World urbanisation prospects, the 2011 revision. Country profile: Malawi. New York: United Nations Department of Social and Economic Affairs. http://www.un.org/en/development/desa/ population/publications/pdf/urbanization/WUP2011_Report.pdf. Accessed 10 Oct 2017.

Vedeld, P., Angelsen, A., Bojo, J., Sjaastad, E., \& Berg, G. K. (2007). Forest environmental incomes and the rural poor. Forest Policy and Economics, 9(7), 869-879.

Verduzco-Gallo, I., Ecker, O. \& Pauw, K. (2014). Changes in food and nutrition security in Malawi: Analysis of recent survey evidence. MaSSP working paper 6. Washington, D.C.: International food policy research institute (IFPRI). http://ebrary.ifpri.org/cdm/ref/ collection/p15738coll2/id/128205. Accessed 17 Nov 2017.

Vinceti, B., Eyzaguirre, P. \& Johns, T. (2008). The nutritional role of forest plant foods for rural communities. In: Colfer, C.J.P. (Ed.), Human health and forests: a global overview of issues, practice and policy. Earthscan: London, UK.

Vinceti, B., Termote, C., Ickowitz, A., Powell, B., Kehlenbeck, K., \& Hunter, D. (2013). The contribution of forests and trees to sustainable diets. Sustainability, 5, 4797-4824.

Weisell, R., \& Dop, M. C. (2012). The adult male equivalent concept and its application to household consumption and expenditure surveys (HCES). Food and Nutrition Bulletin, 33(3), 157-162.

WHO. (2004). Vitamin and mineral requirements in human nutrition, second edition. In Report of a joint FAO WHO expert consultation, Bangkok (pp. 194-216). Thailand: World Health Organization.

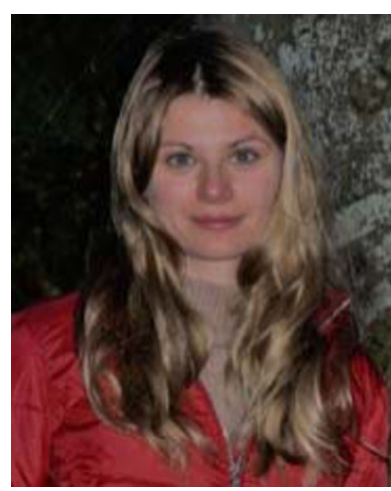

Charlotte Hall is a $\mathrm{PhD}$ candidate in the School of Social Sciences, University of Dundee. She holds a BSc in Environmental Geography and an MSc in Environmental Management, both from the University of Stirling. Her PhD project examines the potential future impact of climate change and land use change in sub-Saharan Africa, using a modelling framework developed under the QUEST-GSI programme, termed FEEDME (Food Estimation and Export for Diet and Malnutrition Evaluation). Her work contributes to the Scottish Food Security Alliance-Crops scheme as well as the Belmont Forum funded Delivering Food on Limited Land (DEVIL) project.

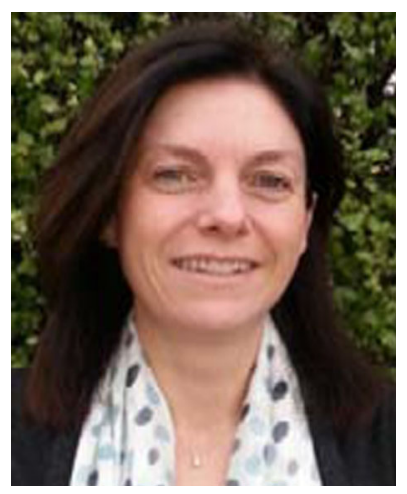

Jennie Macdiarmid is a Professor of Sustainable Nutrition and Health at the University of Aberdeen. She has previously worked at the Universities of Dundee and Leeds. Her research interests include nutrition, food security, climate change and behavioural sciences.

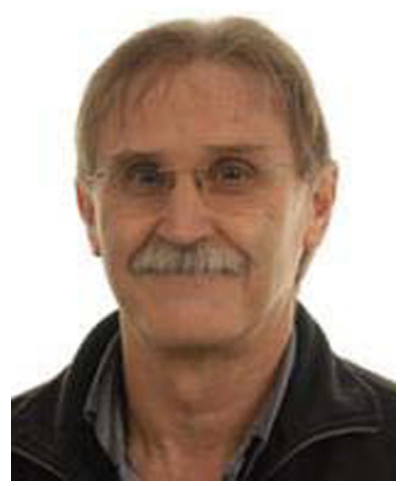

Robin Matthews is Professor of Information and Computational Sciences at the James Hutton Institute. Robin's overall research interests are in the processes of change and adaptation in coupled socio-ecological systems in response to external drivers, and in using complex adaptive systems ideas and integrated modelling approaches, including agentbased models, to understand these processes. He is particularly interested in exploring these ideas in relation to mitigation and adaptation to climate change, and to the provision of ecosystem services. 


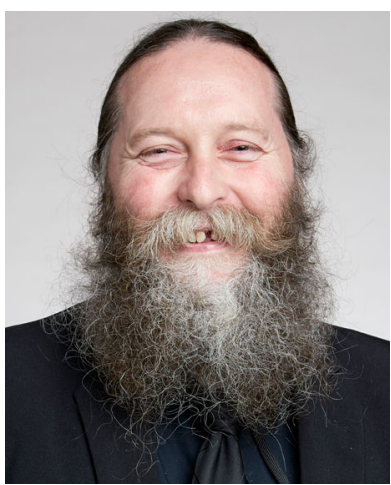

Pete Smith FRS is Professor of Soils and Global Change at the University of Aberdeen (Scotland, UK) and Science Director of the Scottish Climate Change Centre of Expertise (ClimateXChange). His interests are at the interface between food systems, environment and sustainable nutrition.

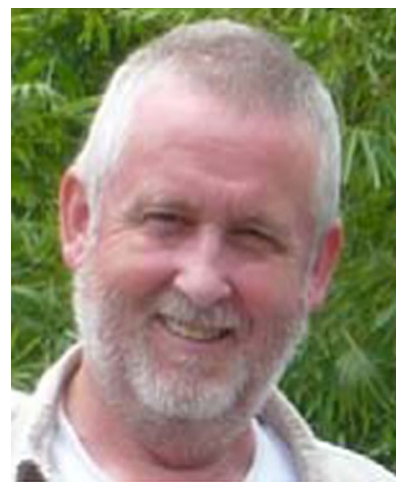

Steve Hubbard is an Honorary Associate Fellow of the James Hutton Institute, Honorary $\mathrm{Research}$ Fellow in Environmental Science at Dundee, and a partner in an ecological and statistical consultancy. Steve's research focuses on the use of mathematical and statistical modelling methods to understand the dynamics of ecological processes such as mosquito-borne disease, infection by intracellular parasites of insects and other arthropods, and the use of natural enemies to replace synthetic chemical pesticides in the control of agricultural pests.
Terry Dawson has been Professor of Global Environmental Change at King's College London since 2016 following earlier academic positions at Oxford, Edinburgh, Southampton and Dundee universities. His research interests include climate change and anthropogenic impacts on biodiversity, natural resources and food security. 